\title{
Land-Cover Legacy Effects on Arbuscular Mycorrhizal Abundance in Human and Wildlife Dominated Systems in Tropical Savanna
}

\author{
Geofrey E. Soka ${ }^{1}$ and Mark E. Ritchie ${ }^{2}$ \\ ${ }^{1}$ Department of Wildlife Management, Sokoine University of Agriculture, P.O. Box 3073, Morogoro, Tanzania \\ ${ }^{2}$ Department of Biology, Syracuse University, New York, NY 13244, USA \\ Correspondence should be addressed to Geofrey E. Soka; gesoka@gmail.com
}

Received 27 November 2015; Accepted 11 January 2016

Academic Editor: Dafeng Hui

Copyright ( 2016 G. E. Soka and M. E. Ritchie. This is an open access article distributed under the Creative Commons Attribution License, which permits unrestricted use, distribution, and reproduction in any medium, provided the original work is properly cited.

\begin{abstract}
Arbuscular mycorrhizal fungi (AMF) can be important mutualists to plant hosts in acquiring soil nutrients. Past work has not explored whether previous land-cover history influences current AMF abundance in croplands and whether different land-cover histories in grazed but not cultivated areas influence AMF. This study was conducted to assess the effects of land-cover history in and near Serengeti National Park on AMF abundance in areas with three different land uses. The results showed that land-cover history influenced a number of soil physicochemical properties following conversion of grassland to cropland or woodland to cropland during the past 27 years. Different original land cover generally did not significantly influence current AMF abundance in croplands or livestock-grazed soils. However, livestock-grazed current grasslands that were formerly woodlands had lower AMF abundance than sites that had been grasslands since 1984. These results suggest that lower AMF abundance in livestock-grazed and cropland areas as compared to protected wildlife-grazed areas may reflect reduced total carbon inputs and higher disturbance and are not strongly influenced by the legacy of previous land cover. Given that recent studies have detected legacy effects on AMF, such effects may reflect more the impact on the taxonomic composition of AMF rather than their total abundance.
\end{abstract}

\section{Introduction}

Arbuscular mycorrhizal fungi (AMF) are ubiquitous soil fungi, forming mutualistic symbiosis with a majority of terrestrial plant species [1-3]. AMF are promising candidates for universal indicators of land management legacies and soil quality degradation [4-6]. The connection between landuse legacies and AMF abundance has been a subject of great interest to the scientific community. Legacy effects of land-use changes have been considered among the most influential disturbances affecting diversity, community structure, and ecosystem functioning and services of microbial communities $[7,8]$. Legacy effects occur when the presence of previous vegetation or land use alters soil properties or organism species pools in ways that persist even if the previous vegetation is changed due to succession, deliberate conversion, or restoration [8-12]. For example, land-use changes have been found to alter the soil characteristics and aboveground species dynamics [13-16] and consequently influence microbial community structure and function [1620]. A chronosequence study along successional gradient has shown that microbial communities tend to become more similar to those in native soils over time [21]. However, residual influence of prior conversion to agriculture has been observed in microbial communities even many years after restoration of forests after agricultural cultivation [22-24].

Soils often continued to reflect their history of previous vegetation and disturbance for many years, through persistent changes in soil chemical and structural properties $[7,9,25,26]$. For example, historical farming in tropic region has resulted in higher soil phosphorous contents and lower soil carbon and nitrogen contents compared to sites with a long continuity of forest cover $[9,27,28]$. Because microbial adaptation and recovery may play a significant 
role in ecosystem responses to human impacts [29-33], the long-term consequences of past land-use decisions on soil microbial communities are crucial for predicting current and future ecosystem functioning and services $[18,34]$. While many studies have found that microbial communities differ in response to land-use legacy $[15,21,35-40]$, there is poor understanding of the association between land-use history and the abundance of AMF in tropical soils.

To help understand the association between land-cover history and soil microbes, the abundance of AMF associated with different land-cover histories in and near the Serengeti was compared. There are three main land uses in the Serengeti region: protected area wildlife-grazed savannas, uncultivated open areas used for livestock grazing, and cultivated fields. Consequently, there are different land-cover histories for each land use, such as transitions from grassland to woodland versus persistent woodland, transition from savanna woodland to grassland versus persistent grassland, or recent conversion of woodland or grassland to cultivation versus persistent cultivation. These land-cover transitions are potentially associated with different current soil properties, such as extractable $\mathrm{P}$, total soil $\mathrm{N}$, and $\mathrm{pH}$. For example, grasslands recently arising from loss of woodland may have higher residual $\mathrm{N}$ or $\mathrm{P}$ in organic matter compared to grasslands that have not recently converted from woodland [41]. Such residual differences among different land-use histories could influence AMF abundance, as a prior study in the Serengeti region [41] found that soil properties varied among different land uses and explained significant variation in AMF hyphal densities. Consequently, AM hyphal abundance was hypothesized to be more strongly influenced by current land-use and less associated with land-cover history because of physical soil disturbance from tillage and reduction in host plant biomass and potentially $\mathrm{C}$ inputs in livestock-grazed sites.

In this study, land-cover classifications of 1984 and 2011 Landsat imagery were used to determine histories for 112 sites in the Serengeti region that were currently (in 2011) in one of the three major land uses. AMF abundance was sampled from multiple soil cores at each site, along with several hypothetically important soil properties, such as extractable $\mathrm{P}$, total soil $\mathrm{N}$, and $\mathrm{pH}$. The association of AMF abundance with land-cover histories for each of the different land uses was determined with ANCOVA to search for influences of land-use histories independent of current differences in soil properties. This paper has significant potential in helping to shape our understanding of the abundance and dynamics of AMF in soils under different land-use/cover classes.

\section{Materials and Methods}

2.1. Study Site Description. Samples were collected inside (wildlife-grazed) Serengeti National Park (SNP), Tanzania, in East Africa $\left(34^{\circ}-36^{\circ} \mathrm{E}\right.$ longitude and $1^{\circ}-2^{\circ} \mathrm{S}$ latitude, Figure 1) and on adjacent open lands that were used either for livestock grazing (livestock grazed) or for cultivated crops (croplands). The area lies approximately about $240 \mathrm{~km}$ south of the equator, resulting in a fairly constant mean monthly temperature and an annual change of only $4-6^{\circ} \mathrm{C}[42]$. The ecosystem is

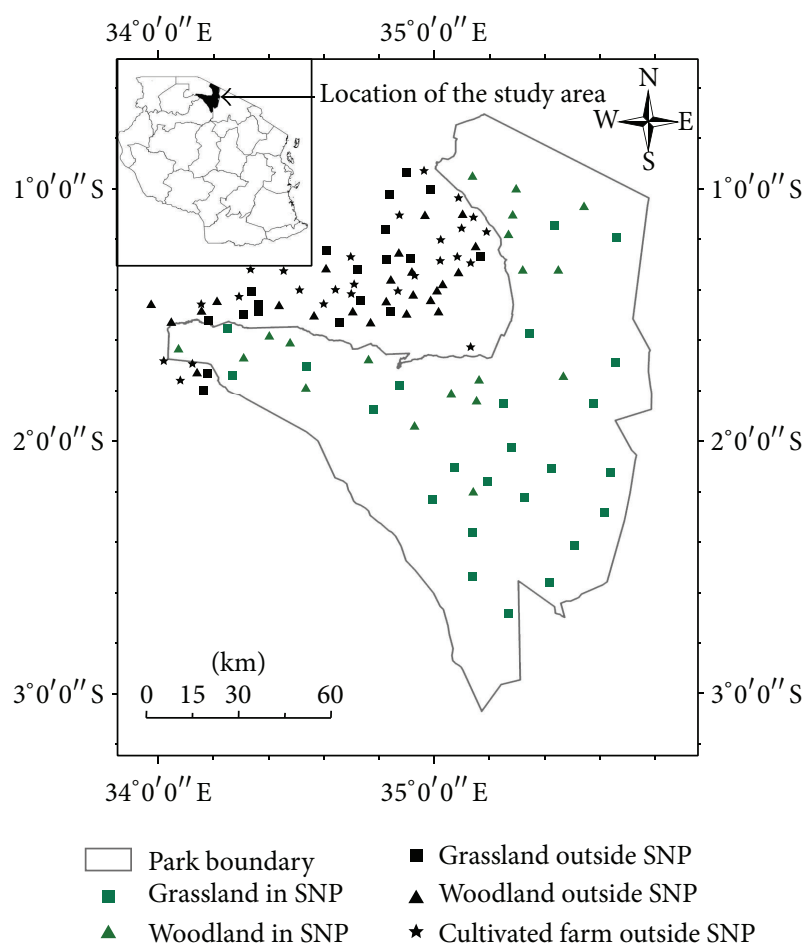

FIGURE 1: Map of study sites and location of study area within Tanzania.

characterized by a bimodal rainfall pattern, with the short rains occurring typically from November to December, the long rains usually taking place between March and May, and a long dry season from June to October. The southeastern Serengeti consists of $\mathrm{C}_{4}$-grass dominated grasslands that shift from short to medium to tallgrass plains towards the north and westward [43]. The northern and western parts of the Serengeti consist predominantly of Acacia woodlands punctuated by large patches of open $\mathrm{C}_{4}$ grassland. This wide variety in vegetation types allows the Serengeti to support over 30 species of ungulates numbering close to 3 million individuals, including 2 million migratory wildebeest (Connochaetes taurinus), zebra (Equus burchellii), and Thomson's gazelles (Gazella thomsonii) that impose the majority of grazing impact [44] which averages $63 \%$ of aboveground biomass each year [43].

The land-use system in and near Serengeti comprises natural woodlands and grasslands inside and outside the park and croplands outside the park. Natural woodland and grassland inside the park are characterized by minimal wildlife grazing intensities while woodland and grassland outside the park are characterized by heavy grazing intensities associated with overgrazing (by cattle) and other human related activities such as charcoal burning, cutting of trees for timber, fire wood, and harvesting of nontimber products. Livestock (mostly cattle but with some sheep and goats) are maintained at relatively high densities sufficient to consume $70-90 \%$ of aboveground biomass (McSherry and Ritchie in preparation). Agricultural systems outside the park comprise small-scale subsistence varieties (Zea mays and Phaseolus 
TABLE 1: Brief description of land-use/cover classes in and near SNP.

\begin{tabular}{|c|c|c|c|}
\hline Land use/cover & Location & Management & Description \\
\hline Grassland in & Inside SNP & Protected area & $\begin{array}{l}\text { Herbaceous vegetation generally below } 2 \mathrm{~m} \text { including } \\
\text { grasses and sedges for wildlife conservation. Fully } \\
\text { protected with strict conservation measures. }\end{array}$ \\
\hline Woodland in & Inside SNP & Protected area & $\begin{array}{l}\text { Areas covered by natural trees (single-stem woody } \\
\text { plants generally taller than } 1.5 \mathrm{~m} \text { at densities }<50 \% \\
\text { canopy cover) for wildlife conservation. Fully protected } \\
\text { with strict conservation measures. }\end{array}$ \\
\hline Cultivated land & Outside SNP & Private land & $\begin{array}{l}\text { Includes areas used for annual crop cultivation. } \\
\text { Maize-bean intercropping system characterized by low } \\
\text { inorganic inputs (an estimate of } 30 \mathrm{~kg} \mathrm{P} \text { and N/ha) } \\
\text { combined with farm yard manure. }\end{array}$ \\
\hline Grassland out & Outside SNP & Public land & $\begin{array}{l}\text { Herbaceous vegetation generally below } 2 \mathrm{~m} \text { including } \\
\text { grasses and sedges used for communal grazing. }\end{array}$ \\
\hline Woodland out & Outside SNP & Public land & $\begin{array}{l}\text { Represents areas covered by trees (single-stem woody } \\
\text { plants generally taller than } 1.5 \mathrm{~m} \text { at densities }<50 \% \\
\text { canopy cover) used for communal grazing. }\end{array}$ \\
\hline
\end{tabular}

TABLE 2: Remotely sensed data used in the analysis of land-use/cover change in and near SNP.

\begin{tabular}{|c|c|c|c|c|}
\hline Sensor & Acquisition date & Image ID & Path/row & Season \\
\hline Landsat TM & August 1984 & LT51690611984047XXX02 & $169 / 61$ & Dry \\
\hline Landsat TM & August 1984 & LT51690621984183XXX08 & $169 / 62$ & Dry \\
\hline Landsat TM & August 1984 & LT51700611984366XXX01 & $170 / 61$ & Dry \\
\hline Landsat TM & August 1984 & LT51700621984158XXX01 & $170 / 62$ & Dry \\
\hline Landsat TM and ETM+ & August 2011 & LT51690612011017MLK00 & $169 / 61$ & Dry \\
\hline Landsat TM and ETM+ & August 2011 & LT51690622011017MLK00 & $169 / 62$ & Dry \\
\hline Landsat TM and ETM+ & August 2011 & LT51700612011184MLK01 & $170 / 61$ & Dry \\
\hline Landsat TM and ETM+ & August 2011 & LT51700622011184MLK01 & $170 / 62$ & Dry \\
\hline
\end{tabular}

Note. TM: thematic mapper; ETM+: enhanced thematic mapper plus.

vulgaris) grown with applications of external inorganic fertilizer inputs (estimate of $30 \mathrm{~kg}$ nitrogen and phosphorus per hactare combined with farm yard manure) (Table 1).

2.2. Field Soil Sampling and Soil Laboratory Analyses. The effects of land use/cover changes on AM hyphal abundance across 112 sites $(20 \times 20 \mathrm{~m}$ plot $)$ in the Serengeti region (Figure 1) were studied. Field soil sampling and soil laboratory analyses are detailed in Soka et al. [41]. The extraction and determination of AM hyphal abundance from soils which were collected at each site are summarized in Soka et al. [41]. Soil $\mathrm{pH}$, total nitrogen $(\mathrm{N})$, and available phosphorus (P) were measured at each site to determine how these soil properties were associated with land-cover changes.

\subsection{Remote Sensing Data Collection}

2.3.1. Image Selection, Acquisition, and Analysis. Spatial patterns of land use/cover changes using remote sensing data (1984-2011) derived from the satellite imagery to determine the influence of land-cover history on AM hyphal abundance were established. Landsat $5 \mathrm{TM}$ and $7 \mathrm{ETM}+$ cloud-free with spatial resolution of $30 \mathrm{~m}$ for the Greater Serengeti were acquired from the U.S. Geological Survey (USGS) archive (http://earthexplorer.usgs.gov/). Landsat imagery was selected because it is readily and freely available and frequently used for land-cover classification [45]. The dates were determined by image availability and were paired relatively close in time to help ensure consistency in cover classes and phenology (Table 2). The image processing and classification were performed using the topographical map and landuse map obtained from Tanzania Wildlife Research Institute (TAWIRI). These maps were also used to conduct ground observations to verify the classification results from satellite imagery (Figure 2). To ensure accurate identification of landcover changes and geometric compatibility with other sources of information, the images were geometrically corrected using a 1:50000 scale topographical map and resampled to a local Tanzania UTM coordinate system in UTM zone 36 south of the equator in which Serengeti is located. The images were georeferenced in WGS84 system, UTM zone 36S.

Atmospheric correction was performed to remove the effects of the atmosphere on the reflectance values of images. In order to reinforce visual interpretability of images, a colour composite (Landsat TM bands 3, 4, and 5) was prepared based on their ability to distinguish various vegetation covers. A $3 \times 3$ high pass filter was applied to the colour composite to further enhance visual interpretation of linear features, such as vegetation features. Supervised classification, using 
TABLE 3: Confusion matrix validation of land-cover map 2011.

\begin{tabular}{|c|c|c|c|c|c|}
\hline \multirow[b]{2}{*}{ Reference data } & \multicolumn{5}{|c|}{ Classification data } \\
\hline & Woodland & Grassland & Farmland & Sum & Producer's accuracy \\
\hline Woodland & 28 & 0 & 2 & 30 & 93.3 \\
\hline Grassland & 0 & 32 & 4 & 36 & 88.9 \\
\hline Farmland & 2 & 3 & 26 & 31 & 83.9 \\
\hline Sum & 30 & 35 & 32 & 97 & \\
\hline User's accuracy & 93.3 & 91.4 & 81.3 & & \\
\hline Overall accuracy & 88.7 & & & & \\
\hline
\end{tabular}

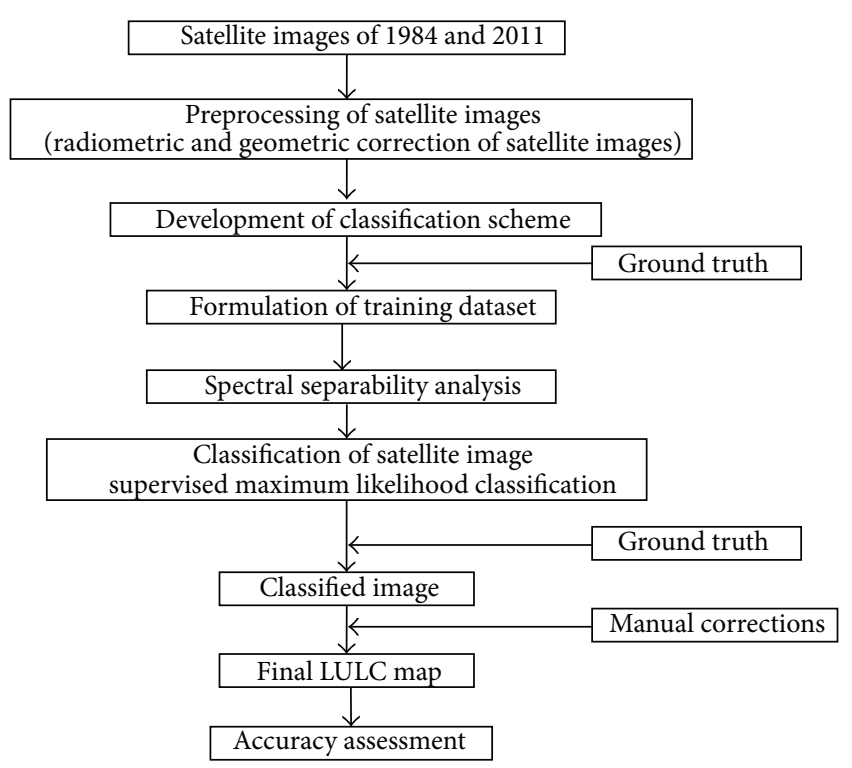

FIGURE 2: Flowchart shows methodology adopted for LULC mapping by Mondal et al. [71].

Maximum Likelihood Classifier, was performed (Figure 2). The training sites on the image, which represent specific land classes to be mapped, were generated by on-screen digitizing of the selected areas for each land-cover class identified on colour composite.

Unsupervised classification for the 1984 Landsat imagery was performed and thereafter subjected to supervised classification using the 2011 training points. No land-cover maps were available for 1984 or around this period. Areas of similar characteristics in both images were visually identified, and for these areas the class of the 2011 image was assigned to the 1984 image. Finally, the classes identified for both 2011 and 1984 were grouped into three land-cover classes: woodland, grassland, and cropland (Table 1). To map land-use change between 1984 and 2011, the following seven land-cover transitions were detected for each land-use category: grassland to grassland, woodland to woodland, cropland to cropland, grassland to cropland, woodland to cropland, grassland to woodland, and woodland to grassland. Transitions from cropland to woodland and cropland to grassland were not detected.

2.3.2. Ground Truth. Land-cover types classified for 2011 were validated with field measurements. A hand held Global
Positioning System (GPS) was used to map locations of various features and sampled land-cover observations. Using the collected ground-truth data, a final classification was done using supervised Maximum Likelihood Classifier (MLC) into three classes of interest (woodland, grassland, and cropland) (Table 1). Each observation plot was given a number and its land cover was recorded on the survey form together with the coordinate location. The development of vegetation cover classes was based on their clear differences in terms of physiognomy observed during the ground truthing and verification. A total of 254 ground-truth points were collected in June 2012 to serve as training samples for the classification; these points were taken in and near Serengeti (Figure 1). Training samples (number of locations and number of pixels) were distributed evenly across classes, where $70 \%$ of the data points were used for training, that is, for classification, and $30 \%$ were used for validation purposes (Table 3 ).

2.3.3. Classification Accuracy Assessment. The accuracy of thematic map was determined by the constructed matrices in order to test whether any difference exists in the interpretation work. The results of the image classification are validated by creating an error (confusion) matrix from which different accuracy measures are derived [46]. The confusion matrix is used to compare spatially coincident ground control points and pixels of the classified image. Table 3 shows a confusion matrix that was established using 86 ground control points (GCP) which were not used in the classification of the 2011 image. The overall accuracy, user's accuracy, and producer's accuracy were estimated from the confusion matrix. The overall accuracy, which is the number of correctly classified pixels, was divided by the total number of GCP (i.e., reference data) used for validation. The overall accuracy in the present study is $88.7 \%$ (Table 3 ).

2.4. Statistical Analyses. AM hyphal abundance associated with land-cover history was compared in three different land uses: wildlife-grazed system, livestock-grazed system, and cultivated soils in and near Serengeti National Park using analysis of covariance (ANCOVA). This approach tests whether or not AM hyphal abundance differed among sites that differed in their original land cover in 1984 compared to different land-use/cover transitions after controlling for relationships between AM hyphal response and three different covariates (soils $\mathrm{P}, \mathrm{N}$, and $\mathrm{pH}$ ) found to be most important in a previous study. Candidate covariates were previously identified from among a much larger set of potential soil and 


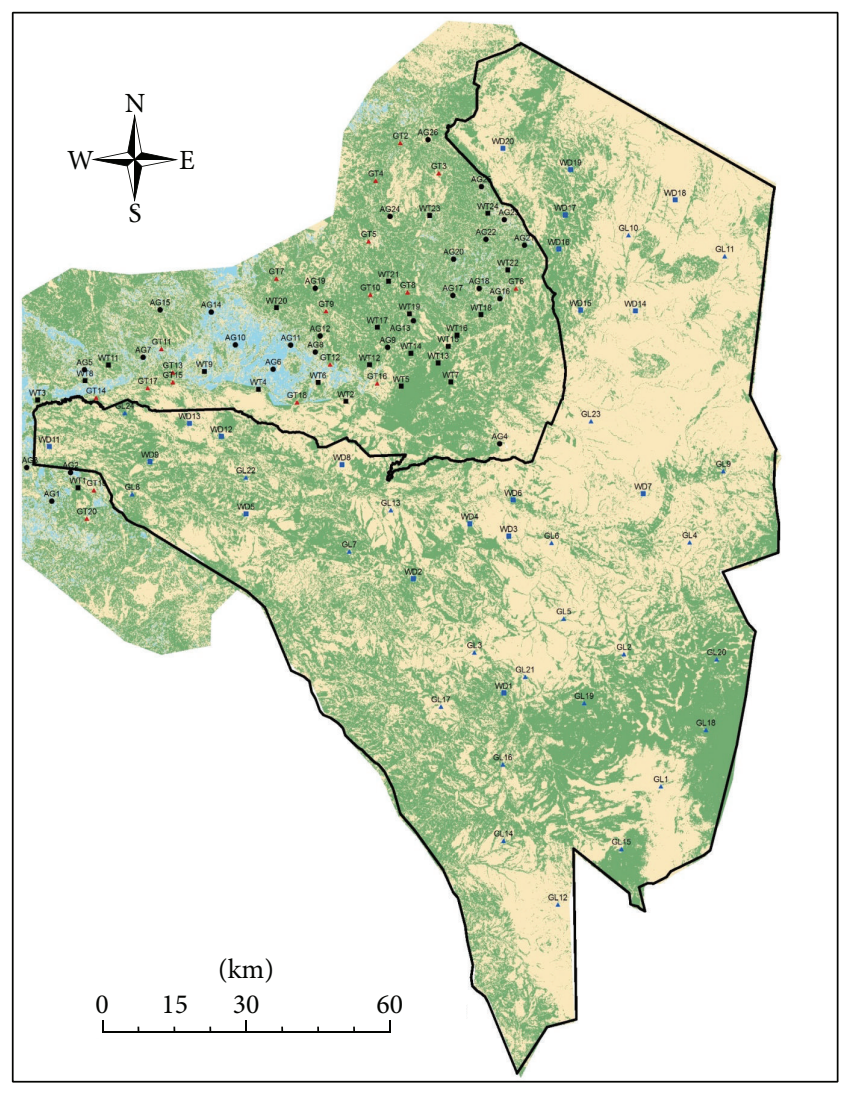

- AG: cropland outside SNP

- GT: grassland outside SNP

- GL: grassland inside SNP

- WD: woodland inside SNP

- WT: woodland outside SNP

FIGURE 3: Land-cover map in and near Serengeti in 1984.

climate variables in previous work at the same study site as shown in Soka et al. [41]. Pairwise comparisons of treatment means associated with different land use/cover changes were made by using Fisher's Protected Least Significant Difference (LSD) at $p<0.05$ confidence level. All statistical analyses were performed using SPSS 17.0 (IBM Corp., Chicago, US).

\section{Results}

3.1. Land-Use/Cover Changes in and near the Park. Generally, the maps (Figures 3 and 4) show the variation in land coverage between the two periods (1984-2011) under consideration. There were visually evident changes in land cover in and near Serengeti; outside the park, areas covered by woodlands have declined while land covers under grasslands and cultivation have expanded. Less visually apparent were frequent transitions from grassland to woodland and vice versa in uncultivated lands both inside and outside the park. A transition matrix (Table 4) summarizes the different landcover conversions detected at the 112 sampling sites.

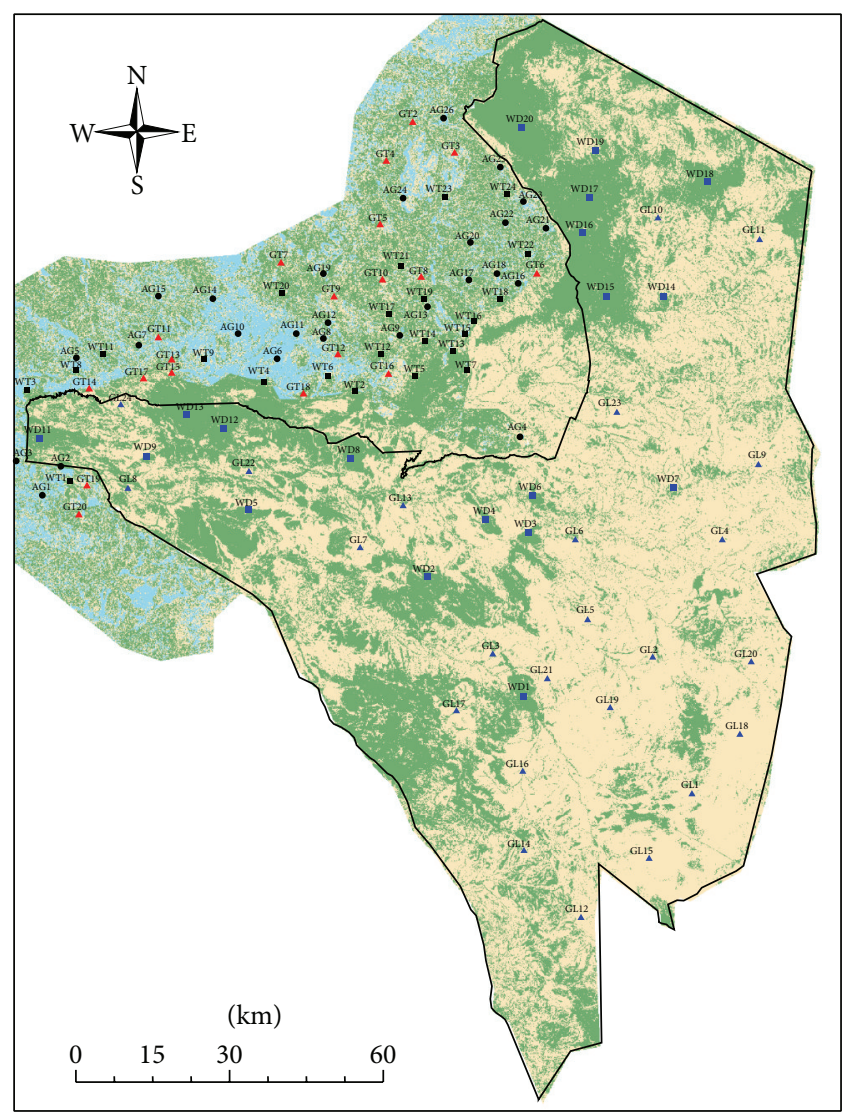

- AG: cropland outside SNP

- GT: grassland outside SNP

A GL: grassland inside SNP

- WD: woodland inside SNP

- WT: woodland outside SNP

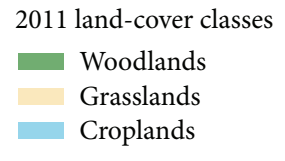

FIgURE 4: Land-cover map in and near Serengeti in 2011.

3.2. Influence of Land-Cover History on Soil Properties. There was no significant influence of land-cover history on soil $\mathrm{P}$ $\left(F_{1,20}=3.17, p=0.09\right)$, soil $\mathrm{pH}\left(F_{1,20}=0.11, p=0.74\right)$, or soil $\mathrm{N}\left(F_{1,20}=0.42, p=0.52\right)$, among the different transitions to croplands or to grassland or to woodland in livestock-grazed sites $\left(F_{2,20}=2.56, p=0.10\right)$. However, there was a significant influence of land-cover history on soil $\mathrm{pH}$ among the different transitions in livestock-grazed soils $\left(F_{3,44}=2.29, p=0.04\right)$. There was a significant influence of land-cover history on soil $\mathrm{P}$ in wildlife-grazed soils $\left(F_{3,43}=\right.$ 3.05, $p=0.04)$ but not on soil $\mathrm{N}$ or $\mathrm{pH}\left(F_{3,43}=2.06, p=\right.$ $0.12)$.

3.3. Linking Land-Use Legacies and AM Hyphal Abundance. There were significant negative correlations between AM hyphal abundance and $\mathrm{P}(r=-0.29, p=0.02)$ and $\mathrm{N}(r=$ $-0.25, p=0.02)$. No significant correlation was observed between AM hyphal abundance and $\mathrm{pH}(r=0.08, p=0.38)$. After controlling for the overall influence of soil properties on AMF abundance, there was no significant association of landcover history with AM hyphal abundance among the different 
TABLE 4: Transition matrix between 1984 and 2011 in and near Serengeti.

\begin{tabular}{|c|c|c|c|c|c|c|}
\hline Land-use type & $\begin{array}{l}\text { Land-cover } \\
\text { history }\end{array}$ & $\begin{array}{l}\text { Number of } \\
\text { plots }\end{array}$ & $\begin{array}{c}\text { AM hyphal } \\
\text { density } \\
\left(\mathrm{m} / \mathrm{cm}^{3}\right) \text { range }\end{array}$ & Soil $\mathrm{pH}$ range & $\begin{array}{l}\text { TN-Kjeld (\%) } \\
\text { range }\end{array}$ & $\begin{array}{l}\mathrm{P}(\mathrm{mg} / \mathrm{kg}) \\
\text { range }\end{array}$ \\
\hline Agriculture & AG-AG & 11 & $17.43-58.38$ & $5.13-7.38$ & $0.01-0.19$ & $0.32-1.27$ \\
\hline Agriculture & GL-AG & 8 & $28.89-92.08$ & $5.40-7.70$ & $0.06-0.21$ & $0.28-1.68$ \\
\hline Agriculture & WL-AG & 6 & $21.30-93.12$ & $5.69-8.25$ & $0.04-0.19$ & $0.53-1.74$ \\
\hline Livestock-grazed system & GL-GL & 15 & $30.13-56.27$ & $6.06-7.86$ & $0.06-0.15$ & $0.35-1.06$ \\
\hline Livestock-grazed system & GL-WL & 8 & $23.82-77.10$ & $5.59-7.57$ & $0.09-0.20$ & $0.04-1.81$ \\
\hline Livestock-grazed system & WL-GL & 7 & $25.22-73.64$ & $5.53-8.23$ & $0.07-0.18$ & $0.21-1.03$ \\
\hline Livestock-grazed system & WL-WL & 14 & $34.40-80.48$ & $5.15-6.56$ & $0.11-0.24$ & $0.26-1.87$ \\
\hline Wildlife-grazed system & GW-GW & 11 & $64.70-106.34$ & $5.79-7.11$ & $0.03-028$ & $0.56-1.73$ \\
\hline Wildlife-grazed system & GW-WW & 8 & $25.22-97.72$ & $5.80-6.89$ & $0.09-0.26$ & $0.31-1.04$ \\
\hline Wildlife-grazed system & WW-GW & 15 & $47.19-94.81$ & $5.59-7.61$ & $0.12-0.28$ & $0.50-1.88$ \\
\hline Wildlife-grazed system & WW-WW & 9 & $46.45-75.35$ & $5.42-7.84$ & $0.11-0.32$ & $0.50-2.06$ \\
\hline
\end{tabular}

AG: agriculture; GL: livestock-grazed grassland; WL: livestock-grazed woodland; GW: wildlife-grazed grassland; WW: wildlife-grazed woodland.

transitions in croplands (Figure 4) $\left(F_{2,20}=2.56, p=0.13\right)$. Within different land uses there was no significant correlation of soil $\mathrm{P}$, soil $\mathrm{N}$, or soil $\mathrm{pH}$ on $\mathrm{AM}$ hyphal abundance among different transitions in croplands $\left(F_{1,20}=3.17\right.$, $p=0.09)$. Land-cover history in livestock-grazed areas was significantly associated with AMF abundance $\left(F_{3,44}=4.56\right.$, $p=0.008$ ) (Figure 5). Post hoc LSD multiple comparisons revealed higher AM hyphal abundance at sites that persisted as grasslands since 1984 as compared to sites that changed from woodland to grassland ( $p=0.02$ ). Also, sites that changed from grasslands to woodlands had significantly lower AMF abundance in livestock-grazed system compared to sites that persisted as woodlands since $1984(p=0.05)$. The unchanged woodlands had the highest abundance of $\operatorname{AMF}\left(56.39 \pm 2.36 \mathrm{~m} / \mathrm{cm}^{3}\right)$ while sites that changed from woodlands to grasslands had the least abundance of AMF $\left(34.61 \pm 4.25 \mathrm{~m} / \mathrm{cm}^{3}\right)$. There were significant main effects of land-cover history on AM hyphal abundance among the different transitions in livestock-grazed soils after controlling for soils properties $\left(F_{3,37}=3.37, p=0.04\right)$. There was no significant main effects of soil $\mathrm{P}$, soil $\mathrm{N}$, or soil $\mathrm{pH}$ on $\mathrm{AM}$ hyphal abundance among different transitions in livestockgrazed soils $\left(F_{1,37}=0.75, p=0.39\right)$.

After controlling for the influence of soil properties, there were significant differences in AM hyphal abundance associated with land-cover history among the different transitions in wildlife-grazed soils $\left(F_{3,43}=4.41, p=0.009\right)$. Post hoc LSD multiple comparisons revealed significantly greater AM hyphal abundance between sites that have persisted as grasslands compared to woodlands that transitioned to grasslands. There were significant main effects of land-cover history on AM hyphal abundance among the different transitions in wildlife-grazed soils $\left(F_{3,36}=3.81, p=0.02\right)$. There were no significant main effects of soil $\mathrm{P}$, soil $\mathrm{N}$, or soil $\mathrm{pH}$ on $\mathrm{AM}$ hyphal abundance among different transitions in wildlifegrazed soils ( $p>0.05$, in all cases).

\section{Discussion}

4.1. Land-Use/Cover Changes in and near Serengeti. The results of the spatial analysis from the supervised

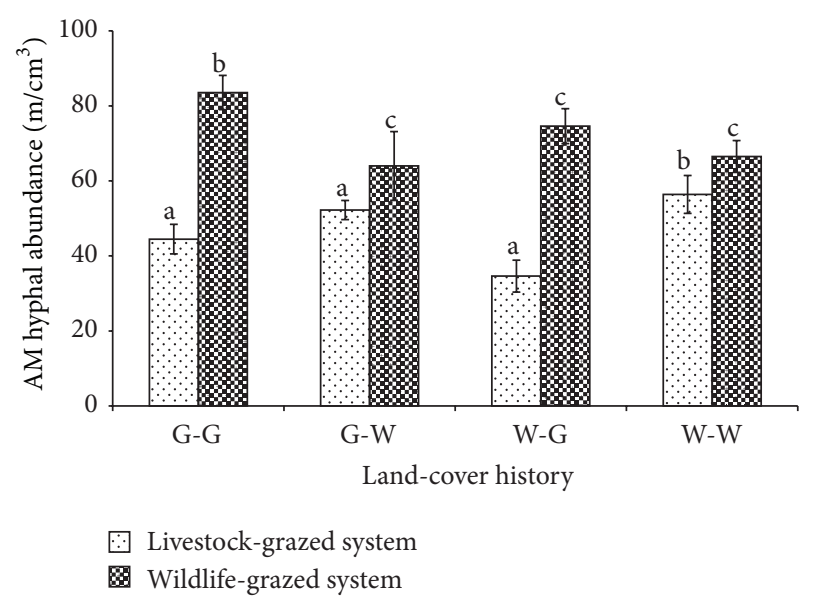

FIGURE 5: Mean $( \pm$ SE) arbuscular mycorrhizal hyphal abundance in soils associated with various land-cover history in livestock and wildlife-grazed systems (G: grassland; W: woodland). Different letters, a, b, and c, indicate significant differences at $p<0.05$.

classification of the images (Figures 3 and 4) indicate noticeable losses and gains in various land-use and landcover types. From the classified images, it is apparent that the area covered by woodland was reduced drastically between 1984 and 2011, with an increase in grasslands and croplands (Figures 3 and 4). Natural vegetation around Serengeti ecosystem has been fragmented by human disturbances through clearance for agricultural activities and pasture [47].

The results of this study suggest that different landcover transitions, that is, legacy effects, had relatively weak impact on AMF abundance. Only transitions from woodland to grassland in both wildlife-grazed and livestock-grazed systems were associated with $15 \%$ lower AMF abundance than that found in persistent grasslands (Figure 5). Notably, sites with transitions from grassland to woodland contained similar AMF abundance as sites that were persistent woodlands, and sites that were converted from either grassland or woodland to cropland (Figure 6) contained similar AMF abundance to persistent croplands. 


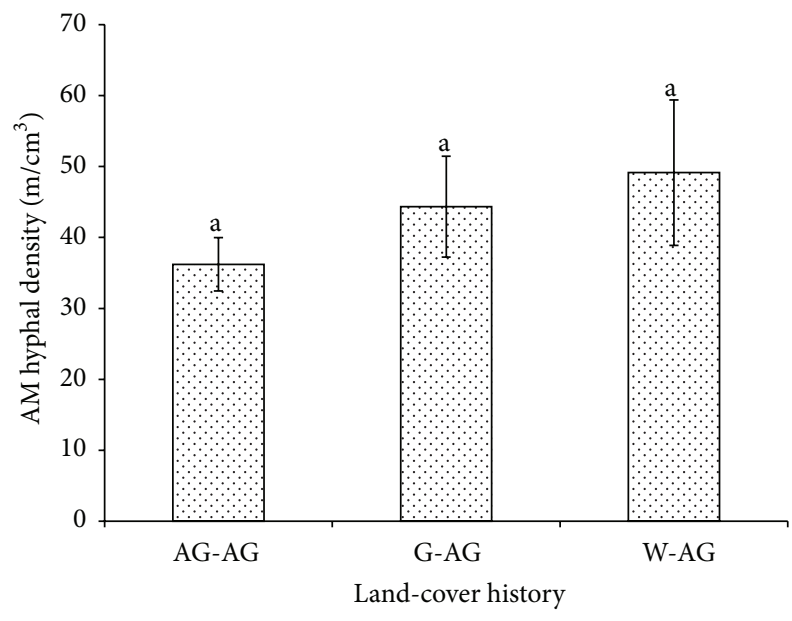

FIgURE 6: Mean $( \pm$ SE) arbuscular mycorrhizal abundance in soils associated with various land-cover history in agricultural sites (AG: agriculture; G: grassland; W: woodland). Means with the same letter are not significantly different from each other $(p<0.05)$.

4.2. Association between Land-Cover History and Soil Properties. The lack of influence of land-cover transitions on AMF abundance may reflect the general lack of association in this Serengeti system between woodland and grassland and key soil properties. A history of woodland resulted in a small depression of $\mathrm{pH}$ that might explain the small reduction in AMF abundance associated with woodland-grassland transitions compared to persistent grasslands in livestockgrazed sites, but the change in $\mathrm{pH}$ is much lower than what is observed in other woodland to grassland transitions subject to use by humans $[33,47-49]$. One reason for minor shifts in soil properties was that most woodlands in the Serengeti were more closed canopy savannas, with $\mathrm{C}_{4}$ grasses in the understory similar to open grasslands. To the extent that grass understory supports AMF and maintains elevated $\mathrm{pH}$ through the pumping of cations from deep root layers and the recycling of cations in litter, the loss of trees in Serengeti woodlands might have only minor shifts. In protected areas subject to wildlife grazing, there was an increase in soil $\mathrm{P}$ at sites shifting from woodland to grassland as compared to persistent grasslands.

4.3. Association between Land-Use Legacies and AM Hyphal Abundance. However, the overall weak, land-cover history had more influence on AM hyphal abundance in livestockgrazed soils than was the case with either wildlife-grazed or cropland soils. The pattern is similar to the one reported by Aguilar-Fernández et al. [50] who found that forest sites had significantly higher AMF abundance than was the case with livestock-grazed pastures. Several studies conducted some years after forest conversion to pastures have documented a decrease in soil organic matter, microbial biomass, soil microbial activity, and nutrient losses associated with the loss of plant cover [51, 52]. However, in Serengeti, grasslands appear to contain greater AMF abundance than woodlands, perhaps because of greater belowground $\mathrm{C}$ inputs. Also the disruption of soil aggregates and of the processes maintaining longterm soil nutrient and water availabilities contributes to soil deterioration [53]. This study suggests that site-specific differences in soil properties may play a greater role in AM hyphal abundance as observed elsewhere [54-56].

There were significant differences in AM hyphal abundance associated with land-cover history among the different transitions in wildlife-grazed soils. Also there was a significant main effect of land-cover history on AM hyphal abundance among the different transitions in wildlife-grazed soils after controlling for soils properties. This study found that wildlife-grazed grasslands supported the highest AM hyphal abundance possibly due to the presence of more host plant biomass, suggesting that AM hyphal abundance may increase with an increase of host plant biomass and diversity. Woodlands generate a light limited environment under the canopy, which contributed to less ground plant cover (less host plants) leading to grass species suppression. This is in agreement with Burrows and Pfleger [57] who observed an increase in AMF abundance with an increase in plant species diversity. Johnson et al. [58] hypothesize that host plant species may be important for the diversity of AMF species communities.

In this study, many of the transitions may have occurred a few years prior to 2011, and some transitions may have occurred a decade or two earlier. Legacy effects of landuse changes in ecosystem functioning and services may last several hundred years [6,7]. Different past land-cover types have long-term impacts on soil conditions and AMF abundance [6] as observed in this study.

4.4. Effects of Fire on Land Cover. Fire is recognized as a natural and important ecological factor of grassland ecosystems [59]. Fire affects nutrient cycling [60-62], modifies plant species composition $[59,63,64]$, and may have legacy effects on the AMF abundance. Woodland to grassland transitions observed in this study were likely caused by fire in the park and settlement outside the park. Park managers within the Serengeti ecosystem use fire as a valuable tool to maintain the balance between grasslands and woodlands that create the iconic landscapes of the savanna $[65,66]$. The constant presence of fire in the ecosystem has resulted in the evolution of fire-resistant communities of plants that are dependent on periodic burning for their existence [67]. Sometimes wildfires originate from settlement outside the park; its frequency and intensity may have effects on the biotic and abiotic components of grassland and savanna ecosystems [66, 68]. There are accounts of fire effects on ectomycorrhizal density and soil microfungi (e.g., [69]). Gibson and Hulbert [63] reported that the impact of fire has a profound effect on the vegetation. By altering soil temperatures, soil water potential, and plant species composition, burning may have both indirect and direct effects on AM fungal species composition [70].

\section{Conclusions}

It can be concluded that a relatively weak association between land-cover history and soil properties $(\mathrm{pH}, \mathrm{P}$, and $\mathrm{N})$ among the different transitions in and near Serengeti National Park 
was observed. Furthermore, results from this study suggest that there were no relationships between AMF abundance and soil properties ( $\mathrm{pH}, \mathrm{P}$, and $\mathrm{N})$, regardless of the previous land-use history. AMF abundance in croplands was not significantly associated with land-cover history. For livestockgrazed areas, current grasslands that were converted from woodland since 1984 showed lower AMF abundance than areas maintained as grasslands. This suggests that overgrazing by livestock causes the reduction in AM hyphal abundance in the soils by decreasing carbon inputs. Overall, the data suggest that while current land use has a strong association with AMF abundance, land-use history has apparently little effect on AMF abundance although it might have a much stronger influence on species composition than the overall AM hyphal abundance.

Low AMF abundance in livestock areas may reflect a decrease in total carbon inputs and disturbance rather than the legacy of past land use. The degree of current disturbance (tillage and fertilizer) for croplands and reduced carbon inputs from overgrazing might make AMF abundance more vulnerable to legacy effects. A deeper understanding of various past-land-use legacies is crucial, because of their essential role for aboveground and belowground interactions.

\section{Conflict of Interests}

The authors declare that there is no conflict of interests regarding the publication of this paper.

\section{References}

[1] S. Smith and D. Read, Mycorrhizal Symbiosis, Academic Press, London, UK, 1997.

[2] M. C. Rillig, "Arbuscular mycorrhizae and terrestrial ecosystem processes," Ecology Letters, vol. 7, no. 8, pp. 740-754, 2004.

[3] S. Smith and D. Read, Mycorrhizal Symbiosis, Academic Press, Amsterdam, The Netherlands, 3rd edition, 2008.

[4] L. K. Abbott and A. D. Robson, "Factors influencing the occurrence of vesicular-arbuscular mycorrhizas," Agriculture, Ecosystems and Environment, vol. 35, no. 2-3, pp. 121-150, 1991.

[5] A. C. Kennedy and R. I. Papendick, "Microbial characteristics of soil quality," Journal of Soil and Water Conservation, vol. 50, no. 3, pp. 243-248, 1995.

[6] J. Jansa, A. Erb, H.-R. Oberholzer, P. Šmilauer, and S. Egli, "Soil and geography are more important determinants of indigenous arbuscular mycorrhizal communities than management practices in Swiss agricultural soils," Molecular Ecology, vol. 23, no. 8, pp. 2118-2135, 2014.

[7] A. Fichtner, G. von Oheimb, W. Härdtle, C. Wilken, and J. L. M. Gutknecht, "Effects of anthropogenic disturbances on soil microbial communities in oak forests persist for more than 100 years," Soil Biology and Biochemistry, vol. 70, pp. 79-87, 2014.

[8] R. A. Lankau, J. T. Bauer, M. R. Anderson, and R. C. Anderson, "Long-term legacies and partial recovery of mycorrhizal communities after invasive plant removal," Biological Invasions, vol. 16, no. 9, pp. 1979-1990, 2014.

[9] I. Celik, "Land-use effects on organic matter and physical properties of soil in a southern Mediterranean highland of Turkey," Soil and Tillage Research, vol. 83, no. 2, pp. 270-277, 2005.
[10] A. Kulmatiski, K. H. Beard, and J. M. Stark, "Soil history as a primary control on plant invasion in abandoned agricultural fields," Journal of Applied Ecology, vol. 43, no. 5, pp. 868-876, 2006.

[11] P. Kardol, N. J. Cornips, M. M. L. van Kempen, J. M. T. Bakx-Schotman, and W. H. van der Putten, "Microbe-mediated plant-soil feedback causes historical contingency effects in plant community assembly," Ecological Monographs, vol. 77, no. 2, pp. 147-162, 2007.

[12] J. de Chazal and M. D. A. Rounsevell, "Land-use and climate change within assessments of biodiversity change: a review," Global Environmental Change, vol. 19, no. 2, pp. 306-315, 2009.

[13] J. A. Foley, R. DeFries, G. P. Asner et al., "Global consequences of land use," Science, vol. 309, no. 5734, pp. 570-574, 2005.

[14] N. Blaum, E. Rossmanith, and F. Jeltsch, "Land use affects rodent communities in Kalahari savannah rangelands," African Journal of Ecology, vol. 45, no. 2, pp. 189-195, 2007.

[15] C. L. Lauber, M. S. Strickland, M. A. Bradford, and N. Fierer, "The influence of soil properties on the structure of bacterial and fungal communities across land-use types," Soil Biology and Biochemistry, vol. 40, no. 9, pp. 2407-2415, 2008.

[16] M. Aubert, P. Margerie, J. Trap, and F. Bureau, "Abovegroundbelowground relationships in temperate forests: plant litter composes and microbiota orchestrates," Forest Ecology and Management, vol. 259, no. 3, pp. 563-572, 2010.

[17] G. Chen, L. Gan, S. Wang, Y. Wu, and G. Wan, "A comparative study on the microbiological characteristics of soils under different land-use conditions from Karst areas of Southwest China," Chinese Journal of Geochemistry, vol. 20, no. 1, pp. 52$58,2001$.

[18] F. L. Carpenter, S. P. Mayorga, E. G. Quintero, and M. Schroeder, "Land-use and erosion of a Costa Rican Ultisol affect soil chemistry, mycorrhizal fungi and early regeneration," Forest Ecology and Management, vol. 144, no. 1-3, pp. 1-17, 2001.

[19] S. J. Grayston and H. Rennenberg, "Assessing effects of forest management on microbial community structure in a central European beech forest," Canadian Journal of Forest Research, vol. 36, no. 10, pp. 2595-2604, 2006.

[20] K. S. Ramirez, J. M. Craine, and N. Fierer, "Consistent effects of nitrogen amendments on soil microbial communities and processes across biomes," Global Change Biology, vol. 18, no. 6, pp. 1918-1927, 2012.

[21] K. Jangid, M. A. Williams, A. J. Franzluebbers, T. M. Schmidt, D. C. Coleman, and W. B. Whitman, "Land-use history has a stronger impact on soil microbial community composition than aboveground vegetation and soil properties," Soil Biology and Biochemistry, vol. 43, no. 10, pp. 2184-2193, 2011.

[22] K. E. Giller, M. H. Beare, P. Lavelle, A.-M. N. Izac, and M. J. Swift, "Agricultural intensification, soil biodiversity and agroecosystem function," Applied Soil Ecology, vol. 6, no. 1, pp. 3-16, 1997.

[23] Y.-J. Jiang, D.-X. Yuan, C. Zhang et al., "Impact of land-use change on soil properties in a typical karst agricultural region of Southwest China: a case study of Xiaojiang watershed, Yunnan," Environmental Geology, vol. 50, no. 6, pp. 911-918, 2006.

[24] J. M. Fraterrigo, T. C. Balser, and M. G. Turner, "Microbial community variation and its relationship with nitrogen mineralization in historically altered forests," Ecology, vol. 87, no. 3, pp. 570-579, 2006.

[25] K. Verheyen, B. Bossuyt, M. Hermy, and G. Tack, "The land use history (1278-1990) of a mixed hardwood forest in western 
Belgium and its relationship with chemical soil characteristics," Journal of Biogeography, vol. 26, no. 5, pp. 1115-1128, 1999.

[26] J. H. Jussy, W. Koerner, E. Dambrine, J. L. Dupouey, and M. Benoit, "Influence of former agricultural land use on net nitrate production in forest soils," European Journal of Soil Science, vol. 53, no. 3, pp. 367-374, 2002.

[27] J. L. Dupouey, E. Dambrine, J. D. Laffite, and C. Moares, "Irreversible impact of past land-use on forest soils and biodiversity," Ecology, vol. 83, no. 11, pp. 2978-2984, 2002.

[28] G. von Oheimb, W. Härdtle, P. S. Naumann, C. Westphal, T. Assmann, and H. Meyer, "Long-term effects of historical heathland farming on soil properties of forest ecosystems," Forest Ecology and Management, vol. 255, no. 5-6, pp. 1984-1993, 2008.

[29] E. F. Lambin, B. L. Turner II, H. J. Geist et al., "The causes of land-use and land-cover change-moving beyond the myths," Global Environmental Change: Human and Policy Dimensions, vol. 11, pp. 261-269, 2001.

[30] E. F. Lambin, H. J. Geist, and E. Lepers, "Dynamics of land-use and land-cover change in tropical regions," Annual Review of Environment and Resources, vol. 28, pp. 205-241, 2003.

[31] S. D. Allison, M. D. Wallenstein, and M. A. Bradford, "Soilcarbon response to warming dependent on microbial physiology," Nature Geoscience, vol. 3, no. 5, pp. 336-340, 2010.

[32] M. D. Wallenstein and E. K. Hall, "A trait-based framework for predicting when and where microbial adaptation to climate change will affect ecosystem functioning," Biogeochemistry, vol. 109, no. 1-3, pp. 35-47, 2012.

[33] R. L. B. Hooke and J. F. Martín-Duque, "Land transformation by humans: a review," GSA Today, vol. 22, no. 12, pp. 4-10, 2012.

[34] B. Sun, Z.-X. Dong, X.-X. Zhang, Y. Li, H. Cao, and Z.-L. Cui, "Rice to vegetables: short-versus long-term impact of land-use change on the indigenous soil microbial community," Microbial Ecology, vol. 62, no. 2, pp. 474-485, 2011.

[35] K. L. Steenwerth, L. E. Jackson, F. J. Calderón, M. R. Stromberg, and K. M. Scow, "Soil microbial community composition and land use history in cultivated and grassland ecosystems of coastal California," Soil Biology \& Biochemistry, vol. 34, no. 11, pp. 1599-1611, 2002.

[36] J. N. Klironomos, "Feedback with soil biota contributes to plant rarity and invasiveness in communities," Nature, vol. 417, no. 6884, pp. 67-70, 2002.

[37] K. M. Batten, K. M. Scow, and E. K. Espeland, "Soil microbial community associated with an invasive grass differentially impacts native plant performance," Microbial Ecology, vol. 55, no. 2, pp. 220-228, 2008.

[38] R. H. A. van Grunsven, W. H. van der Putten, T. M. Bezemer, F. Berendse, and E. M. Veenendaal, "Plant-soil interactions in the expansion and native range of a poleward shifting plant species," Global Change Biology, vol. 16, no. 1, pp. 380-385, 2010.

[39] J. Burton, C. R. Chen, Z. H. Xu, and H. Ghadiri, "Soil microbial biomass, activity and community composition in adjacent native and plantation forests of subtropical Australia," Journal of Soils and Sediments, vol. 10, no. 7, pp. 1267-1277, 2010.

[40] A. M. Koch, P. M. Antunes, and J. N. Klironomos, "Diversity effects on productivity are stronger within than between trophic groups in the arbuscular mycorrhizal symbiosis," PLoS ONE, vol. 7, no. 5, Article ID e36950, 2012.

[41] G. E. Soka, M. E. Ritchie, and E. P. Mayemba, "Influence of current land use and edaphic factors on arbuscular mycorrhizal (AM) hyphal abundance and soil organic matter in and near
Serengeti National Park," Journal of Ecology and the Natural Environment, vol. 7, no. 5, pp. 158-169, 2015.

[42] S. J. McNaughton, "Serengeti grassland ecology: the role of composite environmental factors and contingency in community organization," Ecological Monographs, vol. 53, no. 3, pp. 291-320, 1983.

[43] S. J. McNaughton, "Ecology of a grazing ecosystem: the Serengeti," Ecological Monographs, vol. 55, no. 3, pp. 259-294, 1985.

[44] A. R. E. Sinclair, J. G. C. Hopcraft, H. Olff, S. A. R. Mduma, K. A. Galvin, and G. J. Sharam, "Historical and future changes to the Serengeti ecosystem," in Serengeti III: Human Impacts on Ecosystem Dynamics, A. R. E. Sinclair, C. Packer, S. A. R. Mduma, and J. M. Fryxell, Eds., pp. 7-46, University of Chicago Press, Chicago, Ill, USA, 2008.

[45] M. A. Wulder, J. C. White, S. N. Goward et al., "Landsat continuity: issues and opportunities for land cover monitoring," Remote Sensing of Environment, vol. 112, no. 3, pp. 955-969, 2008.

[46] R. G. Congalton and K. Green, Assessing the Accuracy of Remotely Sensed Data: Principles and Practices, Lewis, London, UK, 1999.

[47] A. B. Estes, T. Kuemmerle, H. Kushnir, V. C. Radeloff, and H. H. Shugart, "Land-cover change and human population trends in the greater Serengeti ecosystem from 1984-2003," Biological Conservation, vol. 147, no. 1, pp. 255-263, 2012.

[48] W. M. Post and L. K. Mann, "Changes in soil organic carbon and nitrogen as a result of cultivation," in Soil and the Greenhouse Effect, A. F. Bowman, Ed., pp. 401-407, John Wiley \& Sons, New York, NY, USA, 1990.

[49] D. Murty, M. U. F. Kirschbaum, R. E. McMurtrie, and H. McGilvray, "Does conversion of forest to agricultural land change soil carbon and nitrogen? A review of the literature," Global Change Biology, vol. 8, no. 2, pp. 105-123, 2002.

[50] M. Aguilar-Fernández, V. J. Jaramillo, L. Varela-Fregoso, and M. E. Gavito, "Short-term consequences of slash-and-burn practices on the arbuscular mycorrhizal fungi of a tropical dry forest," Mycorrhiza, vol. 19, no. 3, pp. 179-186, 2009.

[51] E. B. Allen, M. F. Allen, D. J. Helm, J. M. Trappe, R. Molina, and E. Rincon, "Patterns and regulation of mycorrhizal plant and fungal diversity," Plant and Soil, vol. 170, no. 1, pp. 47-62, 1995.

[52] V. B. Santos, A. S. F. Araújo, L. F. C. Leite, L. A. P. L. Nunes, and W. J. Melo, "Soil microbial biomass and organic matter fractions during transition from conventional to organic farming systems," Geoderma, vol. 170, pp. 227-231, 2012.

[53] F. García-Oliva, R. L. Sanford Jr., and E. Kelly, "Effect of burning of tropical deciduous forest soil in Mexico on the microbial degradation of organic matter," Plant and Soil, vol. 206, no. 1, pp. 29-36, 1998.

[54] D. A. Bossio, M. S. Girvan, L. Verchot et al., "Soil microbial community response to land use change in an agricultural landscape of western Kenya," Microbial Ecology, vol. 49, no. 1, pp. 50-62, 2005.

[55] E. D. C. Jesus, T. L. Marsh, J. M. Tiedje, and F. M. D. S. Moreira, "Changes in land use alter the structure of bacterial communities in Western Amazon soils," The ISME Journal, vol. 3, no. 9, pp. 1004-1011, 2009.

[56] C. J. Eaton, M. P. Cox, and B. Scott, "What triggers grass endophytes to switch from mutualism to pathogenism?" Plant Science, vol. 180, no. 2, pp. 190-195, 2011. 
[57] R. L. Burrows and F. L. Pfleger, "Arbuscular mycorrhizal fungi respond to increasing plant diversity," Canadian Journal of Botany, vol. 80, no. 2, pp. 120-130, 2002.

[58] N. C. Johnson, D. Tilman, and D. Wedin, "Plant and soil controls on mycorrhizal fungal communities," Ecology, vol. 73, no. 6, pp. 2034-2042, 1992.

[59] S. D. Fuhlendorf and D. M. Engle, "Application of the firegrazing interaction to restore a shifting mosaic on tallgrass prairie," Journal of Applied Ecology, vol. 41, no. 4, pp. 604-614, 2004.

[60] N. T. Hobbs and D. S. Schimel, "Fire effects on nitrogen mineralization and fixation in mountain shrub and grassland communities," Journal of Range Management, vol. 37, no. 5, pp. 402-405, 1984.

[61] R. S. Singh, "Effect of winter fire on primary productivity and nutrient concentration of a dry tropical savanna," Vegetatio, vol. 106, no. 1, pp. 63-71, 1993.

[62] C. A. D. M. van de Vijver, P. Poot, and H. H. T. Prins, "Causes of increased nutrient concentrations in post-fire regrowth in an East African savanna," Plant and Soil, vol. 214, no. 1-2, pp. 173$185,1999$.

[63] D. J. Gibson and L. C. Hulbert, "Effects of fire, topography and year-to-year climatic variation on species composition in tallgrass prairie," Vegetatio, vol. 72, no. 3, pp. 175-185, 1987.

[64] D. J. Gibson, "Regeneration and fluctuation of tallgrass prairie vegetation in rresponse to burning frequency," Bulletin of the Torrey Botanical Club, vol. 115, no. 1, pp. 1-12, 1988.

[65] R. A. P. Pellew, "The impacts of elephant, giraffe and fire upon the Acacia tortilis woodlands of the Serengeti," African Journal of Ecology, vol. 21, no. 1, pp. 41-74, 1983.

[66] H. T. Dublin, "Vegetation dynamics in the Serengeti-Mara Ecosystem; the role of elephants, fire and other factors," in Serengeti II: Dynamics, Management, and Conservation of an Ecosystem, A. R. E. Sinclair and P. Arcese, Eds., pp. 71-90, University of Chicago Press, Chicago, Ill, USA, 1995.

[67] P. M. Olindo, "Fire and conservation of the habitat in Kenya," in Proceedings of the Annual Tall Timbers Fire Ecology Conference, vol. 11, pp. 243-257, Tallahassee, Fla, USA, June 1971.

[68] W. J. Bond and B. W. van Wilgen, Fire and Plants, Chapman \& Hall, London, UK, 1996.

[69] P. Reddell and N. Malajczuk, "Formation of mycorrhizae by jarrah (Eucalyptus marginata Donn. ex Smith) in litter and soil," Australian Journal of Botany, vol. 32, no. 5, pp. 511-520, 1984.

[70] D. J. Gibson and B. A. D. Hetrick, "Topographic and fire effects on the composition and abundance of VA-mycorrhizal fungi in Tallgrass prairie," Mycologia, vol. 80, no. 4, pp. 433-441, 1988.

[71] M. S. Mondal, N. Sharma, M. Kappas, and P. K. Garg, "Modeling of spatio-temporal dynamics of land use and land cover in a part of Brahmaputra River basin using Geoinformatic techniques," Geocarto International, vol. 28, no. 7, pp. 632-656, 2013. 

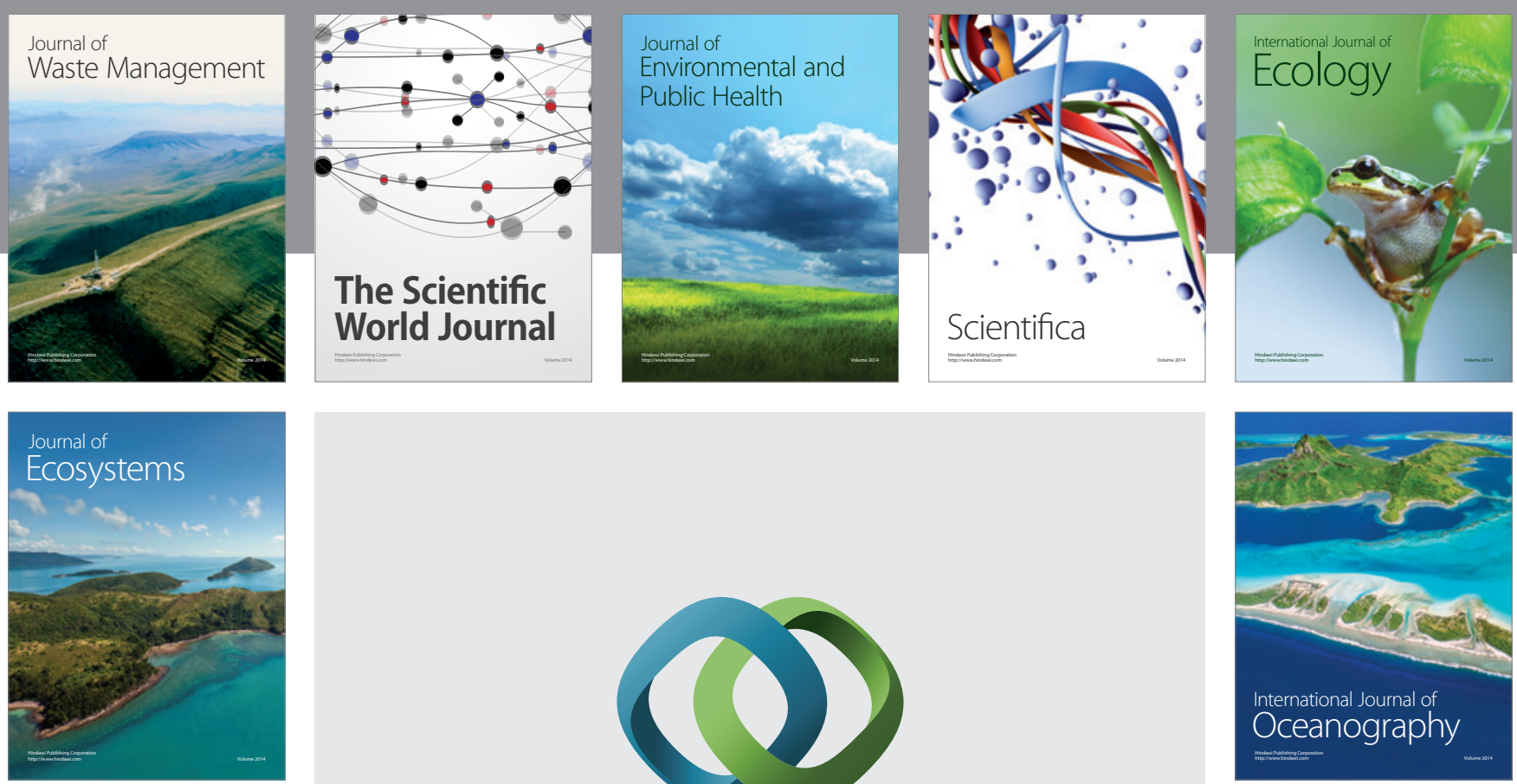

The Scientific World Journal
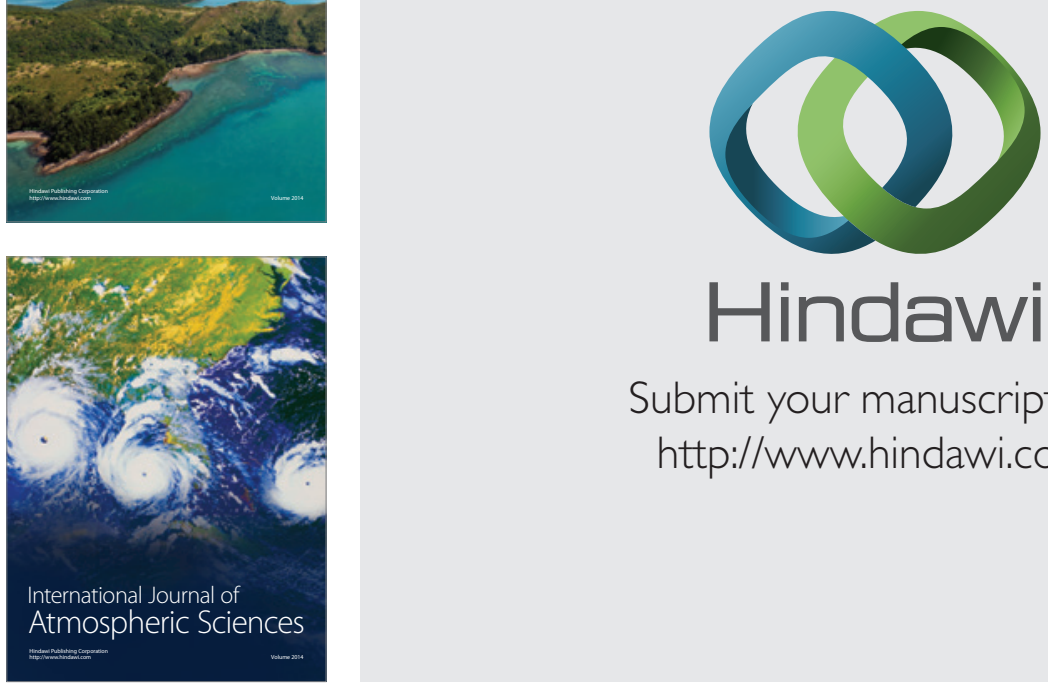

\section{Hindawi}

Submit your manuscripts at

http://www.hindawi.com
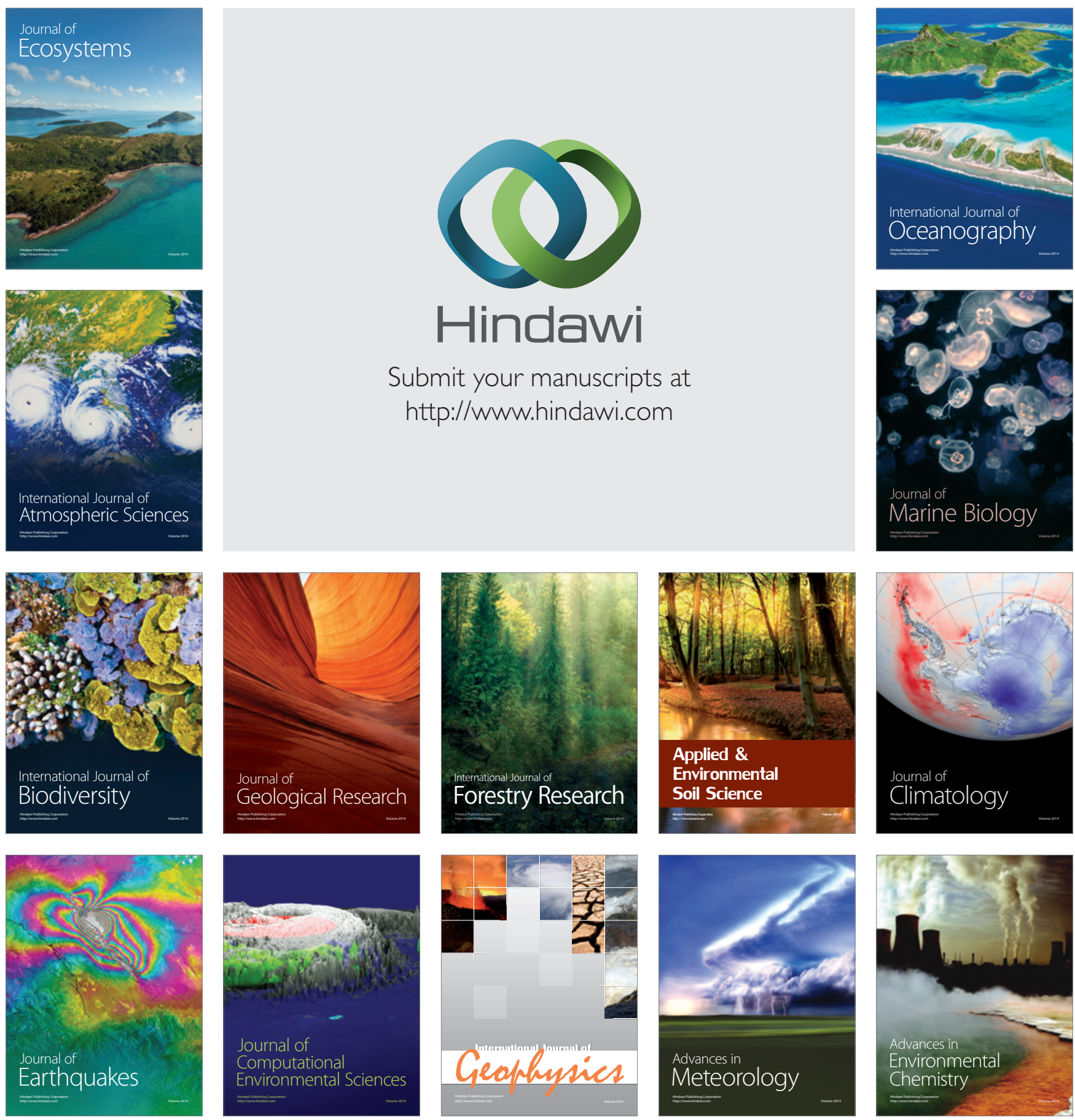